\title{
New records of 45 bird species in the desert margins area of the North- West Province, South Africa
}

\section{A. Hudson \& H. Bouwman}

\begin{abstract}
Hudson, A. \& H. Bouwman. 2006. New records of 45 bird species in the desert margins area of the North-West Province, South Africa. Koedoe 49(1): 91-98. Pretoria. ISSN 0075-6458.
\end{abstract}

\begin{abstract}
New records and possible range extensions are reported on 45 bird species (ca 25\% of the 167 species recorded during surveys) in the Bophirima district of the North-West Province, South Africa. The findings were compared with data in The Atlas of Southern African Birds. The main reasons for these new records may be ascribed to the low number of visits during the atlas project, higher precipitation during the time of our observations versus that of the atlas project, and possibly an increased suitability of the area for some bird species due to human habitation. These new records also provide additional information that may be useful in conservation planning, especially in arid areas. Heuningvlei Pan in particular, should be considered for additional conservation measures.
\end{abstract}

Key words: arid areas, Molopo Nature Reserve, Heuningvlei Pan, wetland.

Adrian Hudson $ه($ drkah@puk.ac.za) \& Henk Bouwman, School for Environmental Sciences and Development (Zoology), North-West University (Potchefstroom Campus), Private Bag X6001, Potchefstroom, South Africa.

\section{Introduction}

Birds, to a greater extent than other animals, have the ability to move away from adverse conditions and towards areas with more favourable conditions (Dean 2004). Their ability to fly reduces the significance of distance from one area to the other, and negates boundaries that would keep other species (such as larger game) restricted to a certain area (O' Halloran et al. 2002).

The two basic strategies desert animals use for survival are to be sedentary and using behavioural or physiological adaptations, or to move seasonally or opportunistically to more suitable areas (Dean 2004). One form of migration found in birds, including desert birds, is nomadism (Dean 2004). Nomadism occurs when birds move from area to area in order to utilise spatially and temporally patchy resources. Nomadic avifauna is characterised by the dramatic increase of numbers of birds in suitable areas or decrease in unsuitable areas.
The topic of a great deal of modern-day literature is the dynamic environment in which we as humans and other organisms on earth find ourselves (Parody et al. 2001). Stochastic, natural and long-term alterations of the environment can take on various forms, namely, changing climatic conditions, changing geological structure and concomitant changes in vegetation structure. The environmental changes can also be of an anthropogenic nature. Humans change the environment in a number of ways, for instance: changing watercourses, draining wetlands, destruction of natural habitats for various reasons, urbanisation or practices that promote desertification. These can all lead to areas becoming unsuitable for bird species that previously occurred in that area (Parody et al. 2001). Other anthropogenic influences may even increase an area's suitability for birds. Thousands of small man-made wetlands are being constructed due to watering points in the more arid areas of Southern Africa to provide water for livestock. Large areas of grain crops are providing food 


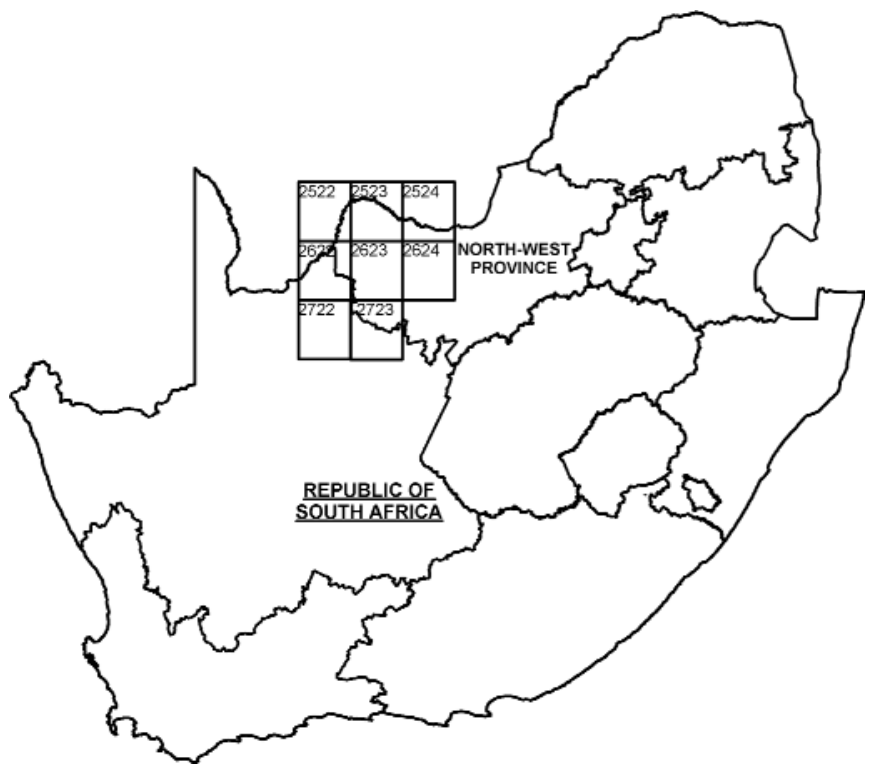

Fig. 1. Location of grids for new records of bird species, in the Bopherima district of the North-West Province, South Africa.

sources for granivorous birds. Tree plantations are providing suitable habitats for some tree dwelling birds in areas where they did not previously exist, and urbanisation is providing additional habitats for a number of species in areas with an otherwise flat topography (Hockey 2003). The changing environment is causing bird species to move away from habitats that have become unsuitable, expanding their ranges into areas that have become more suitable. In the $1950 \mathrm{~s}$, the range of Black-chested Prinia Prinia flavicans had a southern boundary that extended as far as the southeastern Free State. By the 1990s, this had shifted as far as the southern Cape coast. Similarly, the African Goshawk Accipiter tachiro occurred only as far as the Eastern Cape in the 1950s, but has expanded its range as far as the Cape west coast (Hockey 2003). Because of these changing ranges it is necessary for ornithologists to regularly update data as to where species occur.

Here we present some significant new records and possible range extensions of birds observed, while on research and train- ing surveys in and around the Molopo Nature Reserve and Heuningvlei Pan in the Bophirima District of the North-West Province (South Africa). Normally new bird records for many areas are to be expected, but the remoteness of the area in question, the increased attention given to desert margin areas in a global context, as well as the number of new records obtained, warrants closer investigation and reporting. The surprising number of new records reported here may also have conservation implications.

\section{Study Area}

The study area (Fig. 1) included four sites in the Bophirima District of the North-West Province in South Africa, ranging from Morokweng $\left(26^{\circ} 27^{\prime} \mathrm{S} ; 2^{\circ} 29^{\prime} \mathrm{E}\right)$ northwestwards to the Botswana border. The vegetation type of the area is Kalahari Plains Thorn Bushveld (Kalahari Thornveld), characterised by a fairly well-developed tree stratum, a moderately-developed shrub stratum and a varying amount of grass cover (Low \& 
Rebelo 1996). The vegetation types of the study sites are identical, but vegetation structure varies due to overgrazing, management practices and/or the use of fire as a management tool in some areas. One site includes a natural saltpan (Heuningvlei; 2623AC) surrounded by heavily overgrazed Kalahari Thornveld. The northwest corner of the pan is edged by a rocky outcrop and fed by a number of permanent freshwater springs. These springs cause that section of the pan to exist as a small but perennial marsh-type wetland with brackish water. Other ephemeral pans - most of them highly impacted by overgrazing and urbanisation-are also located throughout the region. The Molopo Nature Reserve (2522DD) is one of the very few places that can be considered as natural.

\section{Materials and Methods}

The Atlas of Southern African Birds (Harrison et al. 1997a, 1997b) was used as baseline of existing records. The new records reported here are the result of more than 12 surveys, conducted in the area over a four-year period (2003-2006), for various activities in support of the Desert Margins Programme in South Africa. Intensive bird ringing was also done on some of these surveys. None of these surveys were specifically undertaken to gather new records. Binoculars, a telescope, mistnetting equipment, and a global positioning system (GPS) were used. New records were obtained with the following methods:

a) Transects measuring either $500 \mathrm{~m}$ or $1 \mathrm{~km}$ each were surveyed at specific sites over a twentyfour month period. These transects were randomly selected and walked at a constant pace, or were selected based on the condition of the vegetation before and after a fire. Bird species were observed along these transects up to a distance of about $100 \mathrm{~m}$ from the transect centre line. More detailed findings of these transects will be reported elsewhere.

b) Mistnetting was also done at the study sites in order to trap and identify less conspicuous birds (approximately 3000 birds were ringed). Mistnetting was, however, hampered by the openness of the vegetation, heat and strong winds. Mistnetting was carried out strictly according to its code of conduct.

c) Observations of opportunity during transit.

\section{Results}

In total, 167 bird species were identified between July 2002 and February 2006. Of the 167 species observed in the study area, 45 were new records for quarter degree grids when compared with the SA Bird Atlas (Harrison et al. 1997a, 1997b). The species are named and arranged, according to evolutionary relationships, as per Hockey et al. (2005). Brief descriptions of these sightings and conditions follows, and is summarised in Table 1.

White-faced Duck Dendrocygna viduata A group of 13-17 was recorded during each of the surveys at Heuningvlei Pan. This flock appeared to be resident at the pan. No breeding was observed.

Egyptian Goose Alopochen aegyptiaca This bird is common at water bodies throughout the Bophirima District. However, according to Harrison et al. (1997a) this is a new record for grid block 2623AC (Heuningvlei Pan). No breeding was observed.

Cape Teal Anas capensis Eight birds were recorded at Heuningvlei Pan during March and December (2003), but were absent from the site during the winter months.

Yellow-billed Duck

Anas undulata

A small flock of seven birds was recorded during each of the surveys at Heuningvlei Pan. This group also appeared to be resident. No breeding was observed.

Cape Shoveller

Anas smithii

One bird was recorded at Heuningvlei Pan in March 2003. No subsequent sightings were recorded.

Red-billed Teal Anas erythroryncha One bird was recorded at Heuningvlei Pan in March 2003. No subsequent sightings were recorded.

Hottentot Teal Anas hottentota

Two birds were recorded at Heuningvlei 
Pan during March and December (2003), but were absent from the site during the winter months

Greater Honeyguide Indicator indicator One bird of this species was ringed on the Molopo Nature Reserve and another seen on Driefontein communal farm during the March 2003 surveys.

Brown-hooded Kingfisher

Halcyon albiventris

A single bird was sighted during a survey on Molopo Nature Reserve in July 2004.

Eurasian Bee-Eater Merops apiaster European Bee-eaters were recorded once at both Heuningvlei Pan and Molopo Nature Reserve.

Speckled Pigeon

Columba guinea

A large number of these birds were recorded at both Heuningvlei Pan and Driefontein communal farm (2623AD).

\section{African Crake}

Crex egregia

A single individual was recorded at Heuningvlei Pan during the March survey in 2003, but not on any of the subsequent surveys.

\section{Baillons's Crake Porzana pusilla}

A single individual was seen at Heuningvlei Pan in February 2006.

\section{Common Moorhen Gallinula chloropus}

A single individual was recorded at Heuningvlei Pan during the March survey in 2003, but not on any of the subsequent surveys.

\section{Red-knobbed Coot}

Fulica cristata

A large population of between 40-50 individuals appear to be resident at Heuningvlei Pan. These individuals were recorded during all the surveys done at the site and showed little or no variation in numbers. Chicks were observed.

Greenshank

Tringa nebularia

A single bird was seen at Heuningvlei
Pan during the March survey in 2003, but not on any of the subsequent surveys.

Common Sandpiper Tringa hypoleucos Two birds were recorded at Heuningvlei Pan during March and December (2003), but were absent from the site during the winter months

Curlew Sandpiper Calidris ferrugine One or possibly more of this species were seen on two occasions at Heuningvlei Pan.

Ruff

Philomachus pugnax

A single bird was recorded at Heuningvlei Pan, during the March survey in 2003, but not on any of the subsequent surveys.

African Jacana

Actophilornis africana A single bird was sighted during each of the six surveys done at Heuningvlei Pan.

Pied Avocet

Recurvirostra avosetta

A resident group of eight birds seemed to be resident at Heuningvlei Pan. No breeding was observed.

Burchell's Courser

Cursorius rufus

A total of five birds were spotted at different times at Lafras commercial farm (2522DD) and Heuningvlei Pan.

Gymnogene

Polyboroides typus

One individual was recorded at Molopo Nature Reserve in August 2003. No subsequent sightings were recorded

Jackal Buzzard

Buteo rufofuscus

A single individual is resident at Heuningvlei Pan.

Peregrine Falcon Falco peregrinus One individual was recorded at Molopo Nature Reserve in November 2003. No subsequent sightings were recorded

Little Grebe Tachybaptus ruficolli A single bird was recorded at Heuningvlei Pan during the 2003 winter surveys. 
Black-necked Grebe Podiceps nigricolis Two birds were observed at Heuningvlei Pan during all of the surveys, indicating residency.

Black Heron

Egretta ardesiaca

Single birds were recorded during two of the visits to Heuningvlei Pan in 2003.

\section{Grey Heron}

Ardea cinerea

One Grey Heron was recorded during the first survey Heuningvlei Pan. During a later visit a group of five Grey Herons was recorded. These birds do not appear to be resident.

\section{Great Egret}

Casmerodius albus

Single birds were recorded during two of the visits to Heuningvlei Pan in 2003.

\section{Cattle Egret}

Bubulcus ibis

Cattle Egrets are abundant throughout the study area, but according to Harrison et al. (1997a) specimens recorded in grid blocks 2623AC and 2623AD are new records.

\section{Little Bittern}

Ixobrychus minutes

A single bird was observed during the autumn 2003 visit to Heuningvlei Pan. It is probable that this individual was a vagrant.

Greater Flamingo Phoenicopterus rubber Four birds were recorded during each of the December surveys (2003 and 2004) at Heuningvlei Pan. These birds were not recorded during any of the other surveys.

Glossy Ibis

Plegadis falcinellus

A single bird was recorded during a visit to Heuningvlei Pan during March 2003.

Hadeda Ibis

Bostrychia hagedash

Two birds were recorded at the Molopo Nature Reserve. It is quite reasonable to assume that these birds were just passing through the area. However the range of this species has increased greatly over the last two decades (Hockey 2003).
African Spoonbill

Platalea alba

One bird was recorded at Heuningvlei Pan during each of three of the surveys.

White Stork

Ciconia ciconia

Two birds were recorded during a survey at Heuningvlei Pan during 2004. There have been no further sightings of these birds at this location.

Eurasian Golden Oriole Oriolus oriolus This species was recorded on one occasion during the summer survey on the Molopo Nature Reserve.

Greater Striped Swallow Hirundo cucullata This species was recorded on one occasion at Heuningvlei Pan.

Arrow-marked Babbler Turdoides jardineii Four individuals were sighted on one of the transects at Driefontein communal farm in March 2003. These birds were not sighted again during any of the other surveys done in the area.

Dusky Lark

Pinarocorys nigricans

One bird was identified at Heuningvlei Pan during the March 2003 survey, with an additional sighting recorded during December 2003.

Short-Toed Rock-Thrush

Monticola brevipes

This species was recorded on two occasions at Heuningvlei Pan.

Cape Robin-chat

Cosypha caffra

One individual was caught in a mistnet and banded at Heuningvlei Pan in March 2003. The same individual was identified on two subsequent occasions during October 2003 and December 2003.

White-winged Widowbird

Euplectus albonotatus

Two individuals were recorded at Driefontein communal farm (2623AD) during the March 2003 survey. This species was not recorded again during the rest of the study. 
Table 1

New records of bird species in the Bophirima District of the North-West Province, South Africa

\begin{tabular}{|c|c|c|c|c|}
\hline Common name & Species & $\begin{array}{l}\text { Previous } \\
\text { Closest Record }\end{array}$ & New Record & $\begin{array}{l}\text { No. of } \\
\text { sightings }\end{array}$ \\
\hline White-faced Duck & Dendrocygna viduata & 2722AA & $2623 \mathrm{AC}$ & 6 \\
\hline Egyptian Goose & Alopochen aegyptiaca & 2622DD & $2623 \mathrm{AC}$ & 6 \\
\hline Cape Teal & Anas capensis & $2723 \mathrm{AD}$ & $2623 \mathrm{AC}$ & 2 \\
\hline Yellow-billed Duck & Anas undulate & $2622 \mathrm{DC}$ & $2623 \mathrm{AC}$ & 6 \\
\hline Cape Shoveller & Anas smithii & 2723AD & $2623 \mathrm{AC}$ & 1 \\
\hline Redbilled Teal & Anas erythroryncha & $2623 \mathrm{BA}$ & $2623 \mathrm{AC}$ & 1 \\
\hline Hottentot Teal & Anas hottentota & 2722DD & $2623 \mathrm{AC}$ & 2 \\
\hline Greater Honeyguide & Indicator indicator & $2524 \mathrm{CA}$ & $2623 \mathrm{AC}$ & 1 \\
\hline Brown-hooded Kingfisher & Halcyon albiventris & $2623 \mathrm{DC}$ & $2522 \mathrm{DD} \& 2623 \mathrm{AC}$ & 1 \\
\hline Eurasian Bee-Eater & Merops apiaster & $2523 \mathrm{CB}$ & $2522 \mathrm{DD} \& 2623 \mathrm{AC}$ & 1 \\
\hline Speckled Pigeon & Columba guinea & $2623 \mathrm{AD}$ & 2522DD & 6 \\
\hline African Crake & Crex egregia & $2624 \mathrm{BC}$ & $2623 \mathrm{AC}$ & 1 \\
\hline Baillon's Crake & Porzana pusilla & $2523 \mathrm{DC}$ & $2623 \mathrm{AC}$ & 1 \\
\hline Common Moorhen & Gallinula chloropus & $2723 \mathrm{AA}$ & $2623 \mathrm{AC}$ & 1 \\
\hline Red-knobbed Coot & Fulica cristata & $2623 \mathrm{BB} \& 2523 \mathrm{AB}$ & $2623 \mathrm{AC}$ & 6 \\
\hline Greenshank & Tringa nebularia & $2523 \mathrm{DC}$ & $2623 \mathrm{AC}$ & 3 \\
\hline Common Sandpiper & Tringa hypoleucos & $2523 \mathrm{DB}$ & $2623 \mathrm{AC}$ & 2 \\
\hline Curlew Sandpiper & Calidris ferruginea & $2523 \mathrm{BD} \& 2723 \mathrm{CA}$ & $2623 \mathrm{AC}$ & 2 \\
\hline Ruff & Philomachus pugnax & $2623 \mathrm{BB}$ & $2623 \mathrm{AC}$ & 2 \\
\hline African Jacana & Actophilornis africana & $2523 \mathrm{BC}$ & $2623 \mathrm{AC}$ & 6 \\
\hline Pied Avocet & Recurvirostra avosetta & 2623BB & $2623 \mathrm{AC}$ & 6 \\
\hline Burchell's Courser & Cursorius rufus & $2622 \mathrm{AB}$ & $2522 \mathrm{DD} \& 2623 \mathrm{AC}$ & 5 \\
\hline Gymnogene & Polyboroides typus & $2622 \mathrm{AB}$ & $2522 \mathrm{DD}$ & 1 \\
\hline Jackal Buzzard & Buteo rufofuscus & $2624 \mathrm{CB}$ & $2623 \mathrm{AC}$ & 6 \\
\hline Peregrine Falcon & Falco peregrinus & $2723 \mathrm{CC}$ & 2522DD & 1 \\
\hline Little Grebe & Tachybaptus ruficolli & $2623 \mathrm{BC}$ & $2623 \mathrm{AC}$ & 1 \\
\hline Black-necked Grebe & Podiceps nigricolis & $2523 \mathrm{DB}$ & $2623 \mathrm{AC}$ & 6 \\
\hline Black Heron (Egret) & Egretta ardesiaca & $2524 \mathrm{CC}$ & $2623 \mathrm{AC}$ & 2 \\
\hline Grey Heron & Ardea cinerea & $2722 \mathrm{BB}$ & $2623 \mathrm{AC}$ & 1 \\
\hline Great Egret & Casmerodius albus & $2723 \mathrm{AD} \& 2624 \mathrm{CA}$ & $2623 \mathrm{AC}$ & 2 \\
\hline Cattle Egret & Bubulcus ibis & $2622 \mathrm{DD}$ & $2623 \mathrm{AC} \& 2623 \mathrm{AD}$ & 6 \\
\hline Little Bittern & Ixobrychus minutus & 2622DD & $2623 \mathrm{AC}$ & 1 \\
\hline Greater Flamingo & Phoenicopterus ruber & $2723 \mathrm{AD}$ & $2623 \mathrm{AC}$ & 1 \\
\hline Glossy Ibis & Plegadis falcinellus & 2722BB & $2623 \mathrm{AC}$ & 1 \\
\hline Hadeda Ibis & Bostrychia hagedash & $2622 \mathrm{AB} \& 2522 \mathrm{AB}$ & 2522DD \& 2623AC & 2 \\
\hline African Spoonbill & Platalea alba & $2523 \mathrm{AC} \& 2722 \mathrm{BB}$ & $2623 \mathrm{AC}$ & 3 \\
\hline White Stork & Ciconia ciconia & $2722 \mathrm{DC}$ & $2623 \mathrm{AC}$ & 1 \\
\hline Eurasian Golden Oriole & Oriolus oriolus & $2622 \mathrm{AB}$ & 2522DD & 1 \\
\hline Greater Striped Swallow & Hirundo cucullata & $2622 \mathrm{DB}$ & $2522 \mathrm{DD} \& 2623 \mathrm{AC}$ & 1 \\
\hline Arrow-marked Babbler & Turdoides jardineii & 2523DB & $2623 \mathrm{AD}$ & 1 \\
\hline Dusky Lark & Pinarocorys nigricans & $2623 \mathrm{CC}$ & $2623 \mathrm{AC}$ & 1 \\
\hline Short-Toed Rock-Thrush & Monticola brevipes & $2623 \mathrm{AA}$ & $2623 \mathrm{AD}$ & 1 \\
\hline Cape Robin-chat & Cosypha caffra & 2723AD & $2623 \mathrm{AC}$ & 2 \\
\hline White-winged Widowbird & Euplectus albonotatus & 2624AD & $2623 \mathrm{AD}$ & 1 \\
\hline Yellow-Throated Petronia & Petronia superciliaris & $2523 \mathrm{CB}$ & 2522DD & 1 \\
\hline
\end{tabular}


Yellow-Throated Petronia

\section{Petronia \\ superciliaris}

These birds are relatively common in small groups on the Molopo Nature Reserve.

\section{Discussion}

The data collected showed that 45 of the 167 species observed in the study area were present outside of their previously recorded ranges (Table 1). This constitutes ca $25 \%$ of the total number of species identified in the study area since the beginning of 2003. Of these, 26 species were water birds or birds closely associated with water. In this regard the herons, egrets and ducks were conspicuous. These were mostly found at Heuningvlei Pan (the only permanent natural water body within at least $100 \mathrm{~km}$ ), but were also observed on ephemeral pans, when these had water. Some of these pans are closely associated with urban areas. Ganyesa completely encloses one such pan, where Red-knobbed Coot, Ruff and Curlew Sandpipers were observed (these sites have established records). At Morokweng, where the town partially encompasses a larger ephemeral pan, the same birds, larger waders such as Greenshank and Common Sandpiper, as well as Egyptian Goose were also present in low numbers. Heuningvlei also has an associated urban community. When the pan is dry (except for the small permanently inundated corner), people use the pan as a shortcut for motor vehicles and donkey carts (but not intensively), closely skirting the permanently inundated area. The birds seemed to have adapted to this, but some disturbance is evident, and the community seems to be made up of transient birds visiting in summer, rather then permanent residents. Greater Flamingos, African Spoonbills and the larger herons were also regularly observed at Heuningvlei, but with little pattern indicating a transient use of the pan. Ducks, especially the White-faced and Yellow-billed Ducks were always present at Heuningvlei, but no breeding or juveniles were observed.
A recent visit to Heuningvlei Pan (2005) has shown a new threat developing. The dolomitic springs that were previously protected by fencing are now in disrepair, and cattle are grazing within these sensitive areas.

Three new records of raptors were made. A Jackal Buzzard was regularly observed at Heuningvlei (very likely the same individual), while a Gymnogene and Peregrine Falcon was sighted on the Molopo Nature Reserve. This area is well known for its raptors, and the Molopo Raptor Conservancy is closely associated with the reserve.

Speckled Rock Pigeons were only found associated with human habitation, and mostly at Ganyesa and Morokweng. Their numbers seem to be increasing with every visit, and this may therefore constitute a range extension.

For terrestrial birds, most new records were obtained from the Molopo Nature Reserve. The Brown-hooded Kingfisher is a notable new record for this reserve.

Whether these records represent range extensions or just new records of birds in these areas are not clear. Some may be range expansions occurring due to structural changes in the environment caused by management practices. An increase in the amount of surface water available to birds on communal farms, commercial farms and the nature reserve may make the area more habitable for species, such as granivorous birds, that need daily access to water (Hockey 2003). The Atlas of Southern African Birds (Harrison et al. 1997a, 1997b) (which was used as a guide to assess which birds were new records) was compiled from data obtained during a period with below average rainfall (Harrison et al. 1997a, 1997b). This may account for many of the new records for terrestrial birds. This however, does not explain the large number of new records at Heuningvlei Pan, because this area has a permanent water supply. One factor might be the number of cards completed for these areas, during the Southern African Bird Atlas Project. The number of cards completed for 
the 2522DD grid square, in which the Molopo Nature Reserve occurs, was 28. This is not a very high number when compared with the 311 cards that were completed for Potchefstroom for the same project. Only five cards were completed for Heuningvlei Pan, indicating very few visits.

\section{Conclusion}

The new records presented here are probably due to a combination of lack of previous surveys, higher rainfall during this study when compared with the period when data for the Atlas of southern African Birds was collected, and possibly changes in the availability of resources for birds due to human influences. It would appear that the low reporting intensity for this area during the Southern African Bird Atlas Project may be the largest single factor influencing the number of new records.

These new records, combined with those from previous efforts, indicate that existing and additional conservation efforts in arid areas should receive more attention. The large number of birds and species recorded at Heuningvlei (27 new records for waterassociated birds) indicates that the current protection measures should be assessed to enhance the conservation of this apparently important wetland site in this arid region.

\section{Acknowledgements}

We thank the Desert Margins Programme (Klaus Kelner), National Research Foundation and the North-West University (Potchefstroom Campus) for support. We are also indebted to Lieb and Belinda Venter, Leone Hudson, Nikki Smith, Rina and Riaan Booysen, Ester van der Westhuizen and Retha Hoffman for their eyes and ears. We thank Steven Gore, previous Park Warden of the Molopo Nature Reserve, and the North-West Province Parks and Tourism Board for access and permission. Cecile Combrink is thanked for language editing and René Navarro for the data from the Southern African Bird Atlas Project.

\section{References}

Dean, W.R.J. 2004. Nomadic Desert Birds. Berlin: Springer-Verlag.

Harrison, J.A., D.G. Allan, L.G. Underhill, M. Herremans, A.J. Tree, V. Parker \& C.J. BROWn (eds.). 1997a. The Atlas of southern African birds. Volume 1: Non-passerines. Johannesburg: Birdlife South Africa.

Harrison, J.A., D.G. Allan, L.G. Underhill, M. Herremans, A.J. Tree, V. Parker \& C.J. Brown (eds.). 1997b. The Atlas of southern African birds. Volume 2: Passerines. Johannesburg: Birdlife South Africa,

Hockey, P. 2003. Land invasions. Africa Birds and Birding 8(5): 35-41

Low, A.B. \& T.C. ReBelo. 1998. Vegetation of South Africa, Lesotho and Swaziland. Pretoria: Department of Environmental Affairs and Tourism.

O' Halloran, J., P.M. Walsh, P.S. Giller \& T.C. Kelly. 2002. Forestry and bird diversity in Ireland: a management and planning guide. Oikos 79: $247-258$

Parody, J.M., F.J. Cuthbert \& E.H.DeCKer. 2001. The effect of 50 years of landscape change on species richness and community composition. Global Ecology \& Biogeography 10: 305-313. 